\title{
Study on soil burial biodegradation behaviour on polylactic acid nonwoven material as a replacement for petroleum agricultural plastics
}

DOI: 10.35530/IT.072.04.1847

\author{
CRISTINA ELENA STROE \\ TEODOR SÂRBU \\ VASILICA MANEA
}

\author{
FLOAREA BURNICHI \\ DUMITRU MITEL TOMA \\ CĂTĂLINA TUDORA
}

\section{ABSTRACT - REZUMAT \\ Study on soil burial biodegradation behaviour on polylactic acid nonwoven material as a replacement for petroleum agricultural plastics}

Currently, the issues related to environmental pollution with plastics are a major concern. Agriculture is a vital area for human existence, but it generates large amounts of plastic waste. These result from agricultural practices that use systems and support materials which help facilitate the work of farmers and offer a better yield of production and quality of crops, in relation to the smaller areas of agricultural land. An alternative can be the use of sustainable textiles that can bring multiple benefits to the agricultural sector, including: pollution reduction, biodegradation potential, reduced consumption of agricultural inputs like pesticides, herbicides, fertilizers and water, high retention potential for water and good ventilation, increased productivity and quality for the agricultural crops, etc.

First of all, this paper discusses the potential use of bio-based and eco-friendly polymers, such as polylactic acid (PLA), in the form of fibres for the production of non-woven textile structures that can be used as a support element in agricultural practices and for the replacement of conventional plastics obtained from oil resources. Secondly, considering the advantage of the biodegradation property of this material, the durability and the influence of the location depth in a degrading natural environment such as soil, were the target of experiments to highlight the positive aspects of polylactic acid use in the context of the circular economy. To demonstrate the proposed objectives, different physico-mechanical analyses were performed to determine the morphological characteristics of the fibres, the tensile strength, the material thickness and the possible loss of mass due to microbial activity.

Keywords: agro-plastics, polylactic acid fibres, mulching material, biodegradability, life expectancy, waste reduction

\section{Studiu privind comportamentul la biodegradarea prin îngropare în sol a unui material nețesut din acid} polilactic ca înlocuitor al materialelor plastice pe bază de petrol utilizate în agricultură

În prezent, problemele legate de poluarea mediului cu materiale plastice sunt o preocupare majoră. Agricultura reprezintă un domeniu vital pentru existența umană, dar care generează cantități mari de deșeuri din plastic. Acestea rezultă din practicile agricole care utilizează sisteme şi materiale suport ce ajută fermierii şi care oferă un randament mai bun al producţiei şi al calitatii recoltelor, în raport cu suprafeţele tot mai reduse ale terenurilor agricole. O alternativă poate fi utilizarea textilelor durabile, care pot aduce multiple beneficii sectorului agricol, inclusiv: reducerea poluării, potențial de biodegradare, consum redus de input-uri agricole precum pesticide, erbicide, îngrășăminte și apă, potențial ridicat de retenție a apei și o bună ventilație, creșterea productivității și calității culturilor agricole etc.

În primul rând, această lucrare aduce în discuţie potenţialul de utilizare al polimerilor bio şi ecologici, precum acidul polilactic (PLA), sub formă de fibre pentru realizarea de structuri textile de tip neţesut ce pot fi folosite ca element suport în practicile agricole şi pentru înlocuirea materialelor plastice convenţionale obţinute din resurse petroliere. În al doilea rând, luând în considerare avantajul proprietăţii de biodegradare al acestui material, durabilitatea şi influenţa adâncimii de amplasare într-un mediu natural degradant precum solul, au reprezentat ţinta experimentărilor efectuate, pentru a evidenţia aspectele pozitive ale utilizării acidului polilactic în contextul economiei circulare. Pentru a demonstra obiectivele propuse, au fost efectuate diferite analize fizico-mecanice pentru a determina caracteristicile morfologice ale fibrelor, rezistența la tracțiune, grosimea materialului și posibila pierdere de masă datorată activității microbiene.

Cuvinte-cheie: agro-plastice, fibre de acid polilactic, material de mulcire, biodegradabilitate, speranță de viață, reducerea deșeurilor

\section{INTRODUCTION}

Agriculture is an essential field that must keep pace with global change, both from the perspective of ensuring a sufficient amount of food for the increasing population, but also from the perspective of ensuring an optimal quality of food offered to consumers. In this sense, there are more and more common agricultural practices that use systems and support materials to help farmers, to facilitate their work, and provide a better yield of production and quality of crops, concerning the smaller areas of agricultural land.

Greenhouse cover structures, cover materials for seed bed protection, mulching materials, shading 
nets, harvesting systems, etc., are only a few such auxiliary elements which, being made of plastics, at the end of their use require an extra effort to clean the environment of the remaining waste.

Large amounts of plastic waste are generated by the agricultural sector every year. In $2018,5 \%$ of the total post-consumer plastic waste (from 29.1 million tons) in the European Union came from agriculture, immediately after the packaging sector that holds power [1]. Most agricultural plastics are used in only one season and frequent replacement is the key problem of large waste production.

In general, three ways of disposing of petroleum plastic waste are mainly practiced: burial in the ground, incineration and landfilling or disposal along watercourses, ways that have harmful effects on natural ecosystems.

A series of strategies are required to reduce the difficult circumstances generated by the use of plastics in agriculture and to implement a new economy based on the principles of the circular economy, including:

- correct procedures for the collection, disposal and recycling of post-consumer plastics;

- increasing lifetime and performance;

- the introduction and promotion of bio-based materials [2].

In the context of the use of bio-based materials, this study focuses on the potential use of polylactic acid (PLA), one of the many existing biopolymers, in the form of fibres from which nonwoven textiles can be made and used in the agricultural sector (agro-textiles), more exactly to protect and support the growth of crops in the form of mulching material. Mulching foils represent a good part of the total plastic films used by agriculture. According to the report by the Environmental Investigation Agency, in 2018 mulch foils accounted for $40 \%$ of the total agro-plastics market [3], often presenting difficulties in their proper disposal after usage because of contamination with soil. Therefore, the use of bioplastics with the capacity to biodegrade, for such agricultural structures would have a significant contribution to the sustainable development of the sector.

Polylactic acid is thermoplastic polyester produced by the fermentation of a carbohydrate source. The raw materials used to produce PLA can be corn starch, tapioca roots or sugar cane. Its properties are similar to those of conventional plastics, but the advantage is, in particular, the low negative impact on the environment, by its renewable plant nature and biodegradation property. These characteristics triggered its rapid evolution in the textile market as a competitive product with the designation by the FTC as a new type of fibre in 2002 [4, 5].

To declare whether this type of material offers a good performance from the point of view of durability in accordance with the environmental usage conditions and with the functions that it must fulfil as mulching material, it is necessary to study the biodegradation behaviour. It is noted that in the literature there are numerous studies and various approaches that have been performed on the aspect of biodegradation of polylactic acid (PLA) in different biological environments (e.g. composting, soil, seawater) [6] and under different forms. It is most often found in the form of films [7, 8] for testing the biodegradation behavior, but also other forms of PLA material have been studied, depending on the uses: yarns [9], fibres [10], brushes [11], pellets [12], and less in the form of textile material [13].

Biodegradability testing media have shown different results on the mode and the time of evolution, from process initiation to full biodegradation. For example, in soil, under laboratory controlled conditions, a film of polylactic acid goes through a difficult and long process of biodegradation, while in compost it has a much faster rate of biodegradation, due to differences in microbial activity in these environments, according to $[14,15]$. But, in addition to the influence of the presence of microorganisms, equally important for the decomposition process are the humidity and temperature appropriate to the type of microorganisms. In the work realized by $\mathrm{M}$. Karamanlioglu, the tensile strength of a piece of PLA container was lost in 30,36 and 48 days at $50^{\circ} \mathrm{C}$ in compost, soil and sterile water, respectively. However, little or no degradation occurred at lower temperatures $\left(25^{\circ} \mathrm{C}\right.$ and $37^{\circ} \mathrm{C}$ ) over 12 months [16], thus demonstrating the importance of microbial communities, humidity and higher temperature.

The reaction of the material to the biodegradation conditions in the compost was also investigated along with the presence of several types of bacteria additionally added to the test environment to observe which type has a stronger and faster influence on the biodegradation process to remove it from the environment. It was found that the presence of microorganisms such as $A$. sulfonivorans and the Fungus $L$. laccata together with $\mathrm{S}$. viminalis may be an effective tool in accelerating the process of biodegradation of PLA [17]. Another study showed that the action of the bacterium Alcaligenes sp. from the soil caused the complete degradation of a PLA film with the size of $2 \times 2 \mathrm{~cm}^{2}$ after only 20 days [18]. To assess the degree of biodegradation, most studies have used the analysis of $\mathrm{CO}_{2}$ content resulting from the decomposition process [19-24]. Although carbon dioxide is a greenhouse gas that has an impact on climate change, in agriculture, the carbon dioxide released by the decomposition of biodegradable plastics, along with other resulting substances, would also contribute to a great extent in improving soil fertility and supporting plant growth.

In an attempt to contribute to the sustainable development, this article offers a new approach for the valorisation of the potential for use of materials. It is necessary to increase the awareness of the population on the destructive actions generated on the planet, and a first step is to reduce the excessive consumption of resources and materials and to find ways to remedy this fact. By being able to use materials for multiple purposes and by interconnecting areas, such as textiles and agriculture, and using less harmful 
materials, we will be able to reduce much of the pressure on the environment. Thus, the study aimed to test the aerobic biodegradation of a non-woven PLA fibre material in laboratory conditions using as a biodegradation medium a mixture of commercial soil and manure compost, to see if it is a good solution for use as mulch material in terms of durability and elimination of the use of seasonal materials. Also, the influence of burial depth in the soil on the process was verified, as a solution to reduce the effort to remove the material at the end of its useful life.

\section{EXPERIMENTAL PART}

\section{Materials}

A nonwoven material manufactured from $100 \%$ bio based PLA fibres with different lengths and bonded together by a thermic treatment was bought from Toray Industries Company and used in this study.

To assess the material stability and life expectancy, many samples of a similar size were taken from the purchased nonwoven material and were buried into the soil. The soil was a commercial soil type bought from local landscape materials suppliers. This type of soil is composed of $100 \%$ natural soil obtained by black peat processing and improved with natural compost, obtained from manure. It is also a good medium for vegetable growing, ensuring the plants a good supply of water and nutrients. The soil benefit from a $6.5-7.0 \mathrm{pH}$, a humidity grade of $60-70 \%$ and a composition (table 1).

Table 1

\begin{tabular}{|c|c|c|c|c|}
\hline \multicolumn{5}{|c|}{ SOIL COMPOSITION } \\
\hline $\begin{array}{c}\text { Nitrogen } \\
(\%)\end{array}$ & $\begin{array}{c}\text { Phosphor } \\
(\%)\end{array}$ & $\begin{array}{c}\text { Potassium } \\
\mathbf{( \% )}\end{array}$ & $\begin{array}{c}\text { Organic } \\
\text { matter (\%) }\end{array}$ & $\begin{array}{c}\text { C org } \\
(\%)\end{array}$ \\
\hline 1.78 & 0.21 & 0.82 & 34.48 & 13.96 \\
\hline
\end{tabular}

\section{Methods}

\section{Soil burial method}

The applied soil burial method for testing biodegradability in the study did not follow any standards. Three sets of samples were created, with 6 individual samples each, and put into three different containers, according to the test time intervals, in a sandwich soil-fabric structure to evaluate the influence of burial depth on samples. Each sample was covered by $1 \mathrm{~cm}$ of soil, the one at the bottom being covered by $6 \mathrm{~cm}$ of soil. The containers were kept in aerobic conditions according to the time intervals established for the recovery of the samples, listed in the table 2 along with the codification of the samples according to the time and burial depth.

The samples were cut from the original material in the longitudinal direction in a rectangle form with a dimension of $16 \times 29 \mathrm{~cm}$. Also, a set of reference samples with the same size were taken and subjected to the initial physico-mechanical testing methods (tensile strength and elongation, mass and thickness measurements, morphology evaluation) to make a good appreciation of the degree of biodegradability between samples (table 2).

Biodegradation tests were carried out in a chamber with a temperature in the range between 15 and $30^{\circ} \mathrm{C}$ according to the period of the year, in order not to limit the microbial growth and activity of mesophilic microorganisms. Also, the atmospheric humidity was between $40-50 \%$. The room benefited also from the presence of natural light to a certain degree because light also has its influence on the degradation of materials.

\section{Biodegradability testing methods}

- Visual inspection and scanning electron microscopy analysis (SEM)

Each sample was macroscopically analysed after their recovery from the soil to identify any possible changes in their aspect, colour, fragmentation, or any other changes. SEM analysis was used to inspect the morphology of the PLA fibres in the samples before (Nt 0) and after soil burial (Nt 1, Nt 2 and Nt 3). A Quanta FEI 200 equipment was used to record the morphology changes at different levels of magnification.

- Mass variation evolution after biodegradation and thickness measurement

The reweighing of the recovered samples after the end of each proposed degradation interval to evaluate the mass variation is an essential analysis. This determines the possibility of degradation as an effect of destroying the integrity of the material due to the presence of microorganisms and mass loss. After each collection of the samples from the biodegradation medium, they were lightly washed with distilled

\begin{tabular}{|c|l|c|}
\hline \multicolumn{2}{|c|}{ CODING OF SAMPLES AND RECOVERY TIME INTERVAL FROM SOIL } \\
\hline \multicolumn{1}{|c|}{ Coding of samples } & \multicolumn{1}{|c|}{$\begin{array}{c}\text { Samples recovery } \\
\text { time interval from soil }\end{array}$} \\
\hline $\mathrm{Nt} \mathbf{0}$ & Reference sample & - \\
\hline $\mathrm{Nt} \mathrm{1}$ & $\begin{array}{l}\text { Nt 1.1 (the deepest buried), Nt 1.2, Nt 1.3, Nt 1.4, Nt 1.5, Nt 1.6 } \\
\text { (the lowest burial depth) }\end{array}$ & 8 months after soil burial \\
\hline $\mathrm{Nt} \mathbf{2}$ & $\begin{array}{l}\text { Nt 2.1 (the deepest buried), Nt 2.2, Nt 2.3, Nt 2.4, Nt 2.5, Nt 2.6 } \\
\text { (the lowest burial depth) }\end{array}$ & 9 months after soil burial \\
\hline $\mathrm{Nt} \mathrm{3}$ & $\begin{array}{l}\text { Nt 3.1 (the deepest buried), Nt 3.2, Nt 3.3, Nt 3.4, Nt 3.5, Nt 3.6 } \\
\text { (the lowest burial depth) }\end{array}$ & 10 months after soil burial \\
\hline
\end{tabular}


water and then dried at room temperature. The mass variation was determined using equation 1 :

$$
M V(\%)=\frac{W_{0}-W}{W_{0}} \cdot 100
$$

where $M V$ is the mass variation (\%), $W_{0}$ - the initial mass $(\mathrm{g})$ of the sample and $W$ - the mass (g) of the sample after degradation.

Thickness measurement was done according to standard SR EN ISO 5084:2001. Determining the thickness of textile materials and products on digital equipment for measuring fabric thickness, Sylvac S 229. Five measurements were realized for each of the biodegraded samples and also for the reference sample, according to the standard. Measuring points were randomly chosen from the surface of the samples.

- Tensile strength and elongation measurement

The entire tests were done in the Laboratory of physical-mechanical tests for textile materials of INCDTP Romania. Tensile tests were done according to the standard ISO SR EN 29073-3:1998. Textile materials. Nonwoven test methods. Part 3. Determination of tensile strength and elongation. The used equipment was an electronic tester James Heal-Titan (load cell $5 \mathrm{kN}$ ).

The samples subjected to biodegradation were tested from one direction, namely nonwoven delivery direction, only the reference material was tested from both directions, nonwoven delivery direction and cross direction (CD). The test pieces for the tensile measurements had a length of approx. $29 \mathrm{~cm}$ and width of $5 \mathrm{~cm}$. The recommended number of replicates for the test, according to the standard, was 5 pieces per testing direction. The number of test pieces was 3 instead of 5 for the each of samples recovered from soil, according to the surface area. Only the reference sample ( $\mathrm{Nt} 0$ ) was tested on 5 pieces per direction.

\section{RESULTS}

\section{Visual inspection}

The visual inspection of the recovered samples from the soil after the established time intervals for testing the possible degradation indicated some signs of biodegradation, shown in figure 1 and 2 .

In the case of Nt 1 set, recovered at 8 months after the burial in the soil, no significant signs of degradation could be seen at the macro scale, the colour did not change, fragmentation did not occur and the structure was quite rigid, similar to that of the reference samples. An aspect to be mentioned would be that the fibres broke due to the biodegradation process, many ends of the fibrils standing out from the plane of the nonwoven material, more or less for each of the 6 variants, producing a flaky type effect, the most accentuated in the case of sample $\mathrm{Nt} 1.6$, the one located at the lowest depth relative to the soil surface (figure 1).

The Nt 2 and $\mathrm{Nt} 3$ variants registered the same effects as the previous variant, samples Nt 2.6 and

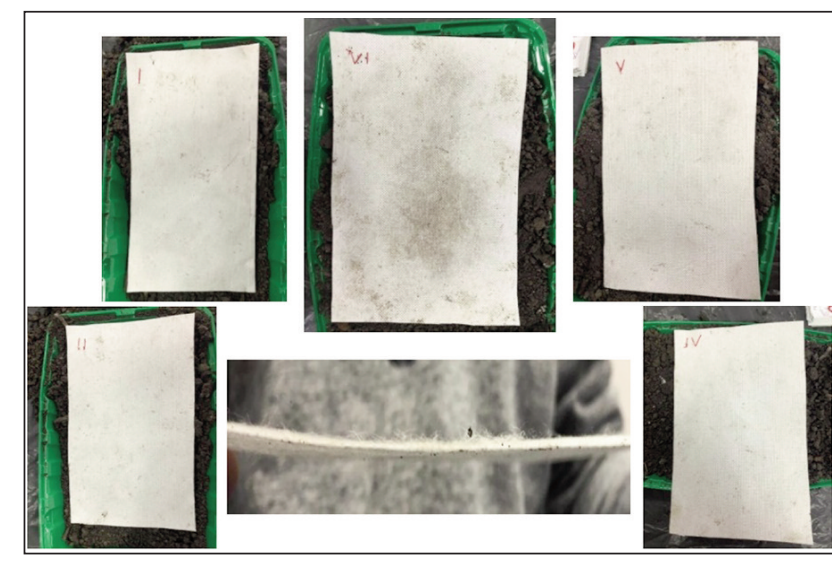

Fig. 1. Sample set $\mathrm{Nt} 1$ as recovered from the test container

Nt 2.3 having the most fibrous surface. But, in this case also an accentuated state of biodegradation it was seen for these samples with a weakened structure (figure 2, a). None of the samples of the Nt 3 variant presented an accentuated fibrous surface; just a few fibres were out of the structure, not necessarily because of the degradation. Nt 3.2 and Nt 3.1 also had a weakened structure, as can be seen from figure $2, b$.

\section{The morphology of the fibres in the sample sets}

The reference sample Nt 0 verified under SEM presents in general perfect smooth cylindrical fibres with a very long length. The measured diameter of the fibres was situated between $9 \mu \mathrm{m}$ and $12 \mu \mathrm{m}$.

All the samples from the set $\mathrm{Nt} 1$ verified after the 8 months of storage in the soil underwent structural changes in the form of thinning, thickening, rupture of the fibres or other deformations, more or less, but the overall diameter of the fibres did not change.

For the Nt 1 set of samples, the most pronounced degradation as a result of many fibres that underwent physical changes was registered in the case of sample Nt 1.3 followed by $\mathrm{Nt} 1.2$ and $\mathrm{Nt} 1.1$. In the case of $\mathrm{Nt} 1.6$ only in a certain portion, there was a lot of damage produced to the fibres. The depth of burial could influence the degradation phenomenon, as we identified that the first three samples $\mathrm{Nt} 1.6, \mathrm{Nt} 1.5$ and $\mathrm{Nt} 1.4$ presented only minor deteriorations in the morphology of the fibres, and the last three ones which are buried at a greater depth showed the most damage.

In the case of the $\mathrm{Nt} 2$ set of samples recovered at 9 months after soil burial, the same morphology changes took place as in the case of the Nt 1 sample set, but more pronounced. Of these, samples $\mathrm{Nt} 2.1$, $\mathrm{Nt} 2.3$, Nt 2.4 and Nt 2.6 showed the most degradation and deformation of the fibres. The rest registering only a few such changes, the sample Nt 2.2 is keeping its appearance almost intact. It seems that in the case of the $\mathrm{Nt} 2$ set the degradation phenomenon did not occur according to a certain rule, the samples being degraded preferentially, not depending on the depth of burial. 


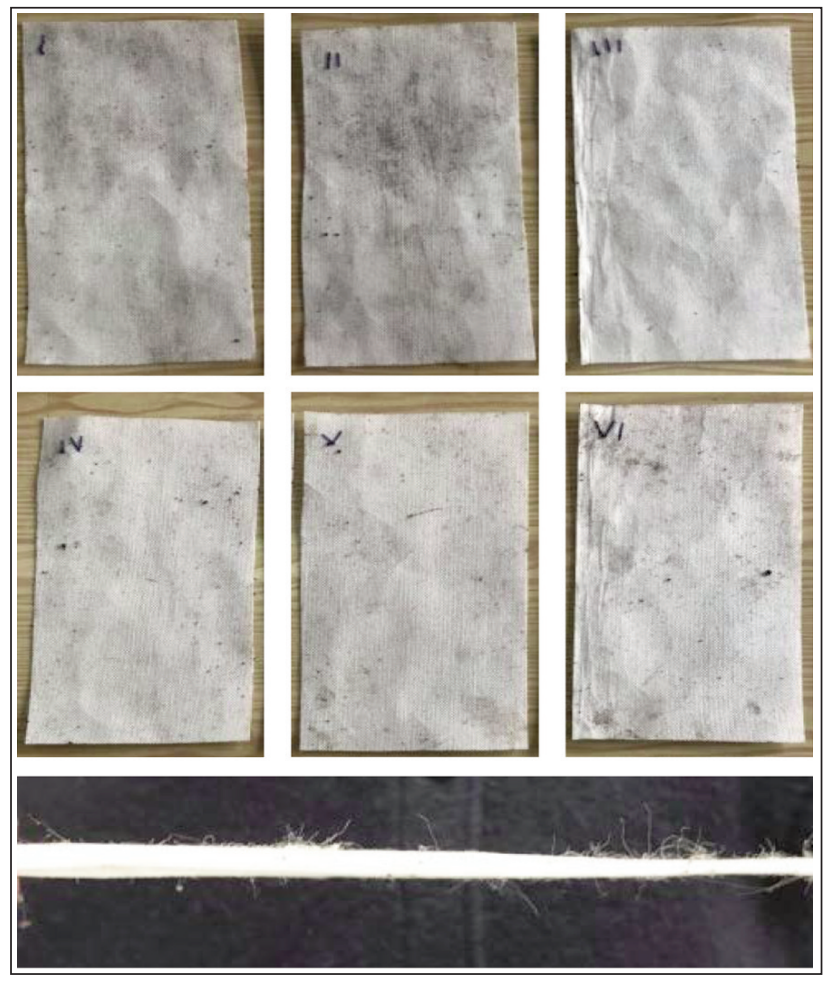

a
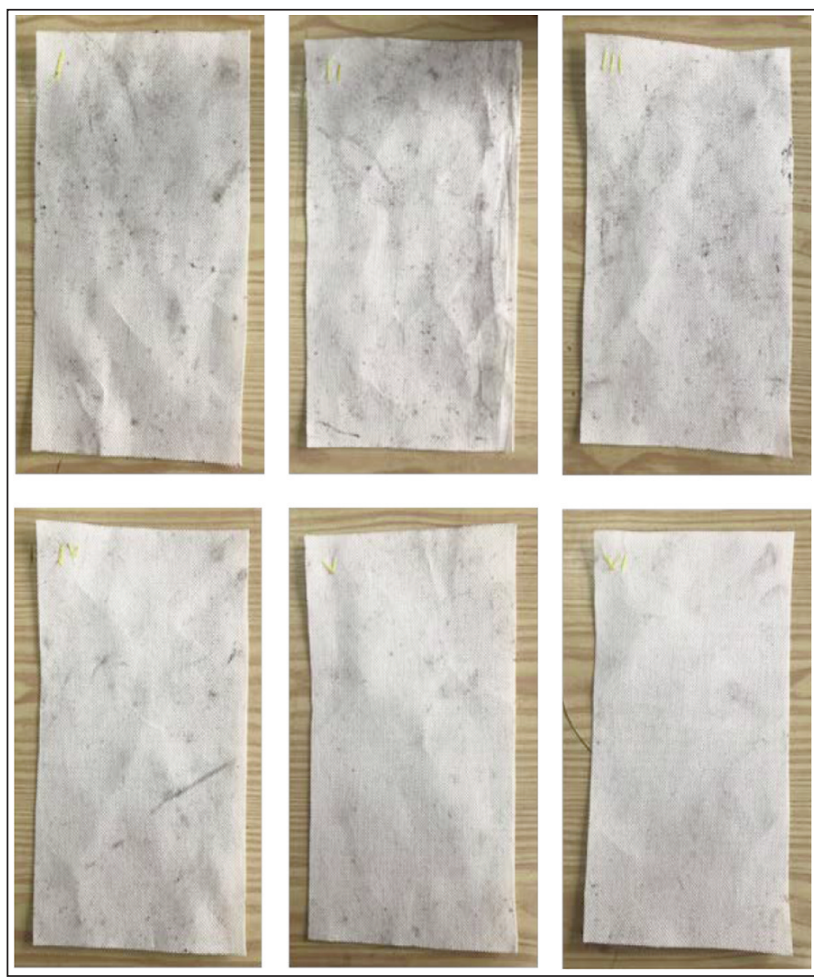

Fig. 2. Sample sets as recovered from the test container: $a-\mathrm{Nt} 2 ; b-\mathrm{Nt} 3$

For the samples set $\mathrm{Nt} 3$ more fibre deteriorations were identified than in the previously analysed sets, by the longer exposure time of biodegradation. Also, the samples Nt 3.5 and Nt 3.6 presented many fibre deteriorations than the rest located deeper in the soil. However, we must mention that the general degree of biodegradation of the samples cannot be estimated accurately based on the images obtained under the microscope, because we analysed only a small portion of each sample, in which we found or not fibre deteriorations, but which probably in the rest of the structure could have shown deteriorations or not, contrary to what we observed under the microscope. Figure 3 highlights the damage caused by bacterial
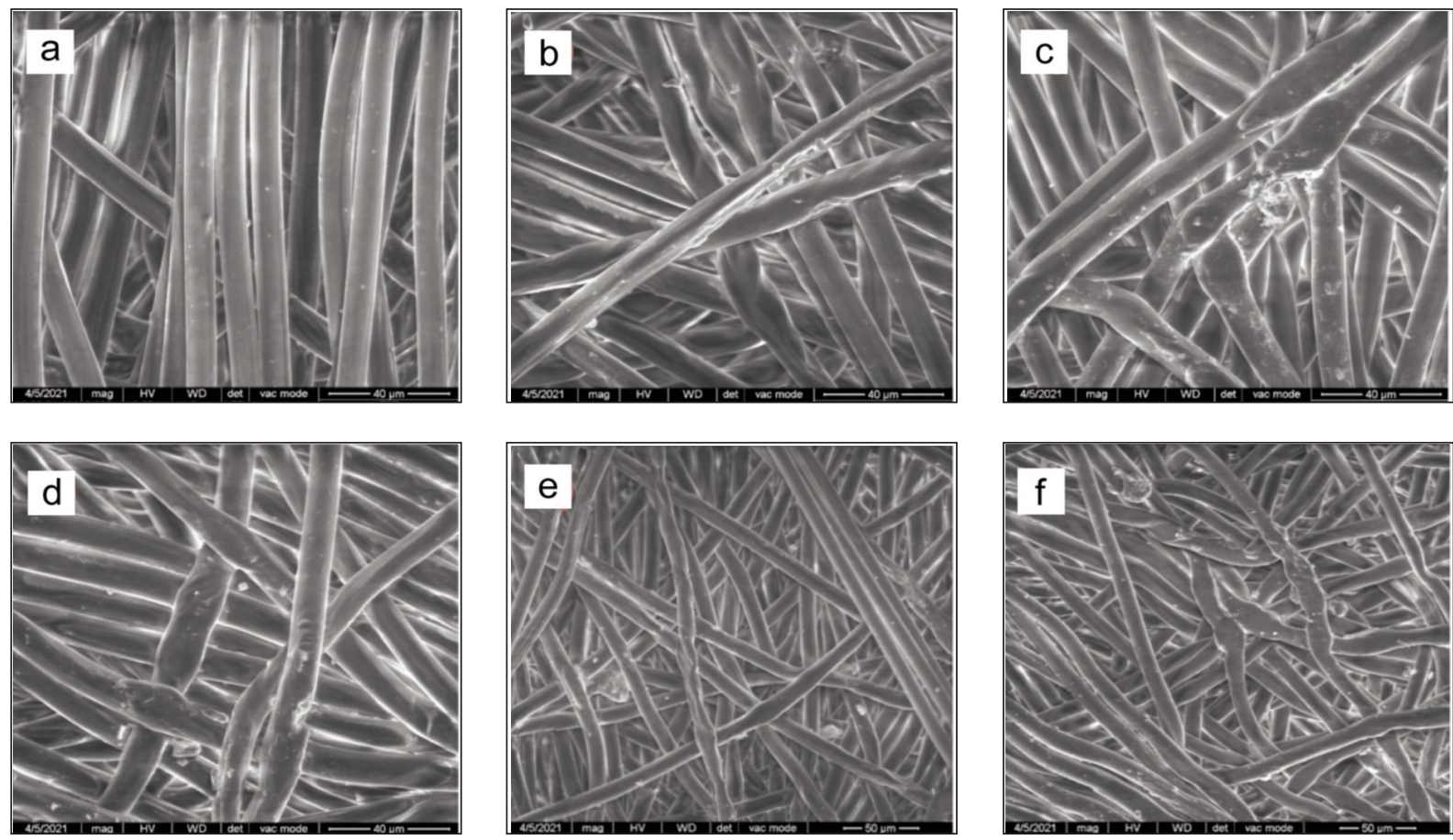

Fig. 3. Morphology of the fibres in the samples: $a-\mathrm{Nt} 0$ at $2000 \times$ magnification; $b-\mathrm{Nt} 1.1$ at $2000 \times$ magnification; $c-\mathrm{Nt} 1.3$ at $2000 \times$ magnification; $d-\mathrm{Nt} 1.6$ at $2000 \times$ magnification; $e-\mathrm{Nt} 2.1$ at $1000 \times$ magnification; $f-\mathrm{Nt} 3.1$ at $1000 \times$ magnification 
activity on the fibres for some of the samples compared to the morphology of the fibres in the reference sample Nt 0 represented in figure 3, a.

\section{Physical characteristics - mass variation, nonwoven thickness}

The mass variation calculated by equation 1 could be a representative indicator of the biodegradability of the samples and the results may be observed in figure 4. As we mentioned above, samples had a dimension of $16 \times 29 \mathrm{~cm}$ and the measured mass according to this dimension was 9.057 grams before their burial in the soil (figure 4).

When the mass variation is positive, an increase in mass above the initial measured value occurred. However, negative variations are associated with mass loss due to microbial activity which destroyed the fibres, as we saw from the SEM micrographs.
Only a few samples (Nt 1.3, Nt 1.6, Nt 2.3, Nt 3.2) from each set corresponding to the three stages of analysis recorded a negative mass variation, for the rest obtaining quite high positive values of the mass variation. This fact can be explained by the intake of soil particles that adhered to the surface of the fibres and filled some of the gaps created by the fibres in the structure, although the samples were carefully washed and dried.

We cannot assume that the burial depth had an influence on the mass loss of the samples and neither the time of burial in the soil which should have provided a significant mass loss compared to the initial mass if the samples had been degraded. Unlike other studies in which plastic films were used to evaluate their degree of biodegradation by mass variation and which after removing the soil allow a more accurate measurement of the mass after biodegradation, in our case, the main problem to the large mass variation measurements remains the residual soil from the structure of the samples.

Another physical characteristic that could indicate the state of biodegradability could be the thickness of the samples after recovery from the soil. Therefore, the thickness was measured for all the three sets recovered from the soil and for the reference set and the results are indicated in table 3.

The samples did not manifest a significant change in their thickness after soil burial in comparison

Fig. 4. Mass variation data of the biodegraded samples

\begin{tabular}{|c|c|c|c|c|c|c|c|}
\hline \multicolumn{8}{|c|}{ THE AVERAGE THICKNESS OF THE REFERENCE AND BIODEGRADED SAMPLES } \\
\hline $\begin{array}{c}\text { Sample } \\
\text { code }\end{array}$ & $\begin{array}{l}\text { Thickness } \\
(\mathrm{mm})\end{array}$ & $\begin{array}{c}\text { Sample } \\
\text { code }\end{array}$ & $\begin{array}{c}\text { Thickness } \\
(\mathrm{mm})\end{array}$ & $\begin{array}{c}\text { Sample } \\
\text { code }\end{array}$ & $\begin{array}{c}\text { Thickness } \\
(\mathrm{mm})\end{array}$ & $\begin{array}{c}\text { Sample } \\
\text { code }\end{array}$ & $\begin{array}{c}\text { Thickness } \\
(\mathrm{mm})\end{array}$ \\
\hline \multirow{6}{*}{ Nt 0} & \multirow{6}{*}{0.69} & Nt 1.1 & 0.69 & Nt 2.1 & 0.69 & Nt 3.1 & 0.69 \\
\hline & & Nt 1.2 & 0.67 & Nt 2.2 & 0.67 & Nt 3.2 & 0.70 \\
\hline & & Nt 1.3 & 0.67 & Nt 2.3 & 0.67 & Nt 3.3 & 0.68 \\
\hline & & Nt 1.4 & 0.67 & Nt 2.4 & 0.70 & $\mathrm{Nt} 3.4$ & 0.68 \\
\hline & & Nt 1.5 & 0.68 & Nt 2.5 & 0.69 & Nt 3.5 & 0.68 \\
\hline & & Nt 1.6 & 0.70 & Nt 2.6 & 0.70 & Nt 3.6 & 0.67 \\
\hline
\end{tabular}


with the reference sample $\mathrm{Nt} 0$, even a slight exceedance of its thickness value occurred. One cause of these small variations in thickness may be rather the not very flat surface of the samples, which in some places showed many wrinkles and not because of the biodegradation process.

\section{Mechanical properties - tensile strength and elongation}

Of all the analyses performed, the tensile test, a mechanical strain, should be the best indicator of the degree of degradation, because if the fibres have gone through a phenomenon of deterioration due to soil microorganisms, but also other environmental factors, such as soil temperature and humidity, atmospheric temperature and humidity, the presence of oxygen or light, the overall strength of the nonwoven structure would have weakened, and the values of breaking strength should be lower than those of the non-degraded sample. In table 4 are presented the average results of the breaking strength measurement $(\mathrm{N})$, along with the elongation at break (\%).

It is mentioned that all the samples buried in the soil were cut in nonwoven delivery direction from the basic fabric, so the results were compared with the results from $\mathrm{Nt} 0$ in this direction. In the case of $\mathrm{Nt} 1$ set the breaking strength is lower than that of the reference sample $\mathrm{Nt} 0$, as well as the elongation, except

Table 4

\begin{tabular}{|c|c|c|}
\hline \multicolumn{3}{|c|}{$\begin{array}{c}\text { AVERAGE MEASUREMENTS OF THE TENSILE } \\
\text { STRENGTH AND ELONGATION OF THE REFERENCE } \\
\text { AND BIODEGRADED SAMPLES }\end{array}$} \\
\hline \multirow{2}{*}{ Samples } & $\begin{array}{c}\text { Breaking strength } \\
\text { (N) }\end{array}$ & $\begin{array}{c}\text { Elongation at break } \\
\text { (\%) }\end{array}$ \\
\cline { 2 - 3 } Nt 0 & \multicolumn{2}{|c|}{ Nonwoven delivery direction results } \\
\cline { 2 - 3 } & \multicolumn{2}{|c|}{ Cross direction results } \\
\cline { 2 - 3 } & 118.73 & 5.61 \\
\hline Nt 1.1 & 414.65 & 5.45 \\
\hline Nt 1.2 & 441.81 & 6.54 \\
\hline Nt 1.3 & 416.68 & 6.75 \\
\hline Nt 1.4 & 458.31 & 7.26 \\
\hline Nt 1.5 & 510.07 & 8.59 \\
\hline Nt 1.6 & 402.54 & 6.29 \\
\hline Nt 2.1 & 511.43 & 8.91 \\
\hline Nt 2.2 & 451.03 & 6.50 \\
\hline Nt 2.3 & 331.96 & 4.59 \\
\hline Nt 2.4 & 525.66 & 8.35 \\
\hline Nt 2.5 & 500.10 & 7.73 \\
\hline Nt 2.6 & 337.87 & 4.40 \\
\hline Nt 3.1 & 491.09 & 7.29 \\
\hline Nt 3.2 & 347.29 & 5.56 \\
\hline Nt 3.3 & 430.89 & 7.79 \\
\hline Nt 3.4 & 380.75 & 5.94 \\
\hline Nt 3.5 & 456.82 & 6.68 \\
\hline Nt 3.6 & 461.41 & 8.34 \\
\hline & & \\
\hline & & 5.19 \\
\hline
\end{tabular}

for $\mathrm{Nt} \mathrm{1.5,} \mathrm{but} \mathrm{it} \mathrm{can} \mathrm{be} \mathrm{considered} \mathrm{that} \mathrm{degradation}$ of the overall structure of the samples has taken place. The lowest breaking strength was obtained in the case of the Nt 1.6 sample, which also recorded a negative mass variation meaning a mass loss compared to the initial mass of the reference sample, but for which we identified only limited deteriorations on the fibres. Also, a low result for the breaking resistance was obtained for Nt 1.3 sample, which corresponds to the loss of mass and even thickness. Even if the other samples did not suffer a mass loss, the lower breaking strength than the reference sample indicated that a certain degree of biodegradation occurred, and it seems that for those buried deeper the results are better. The same cannot be said for the Nt 1.6 sample, which was buried at the lowest depth in the container, but for which we assume a major influence on its damage was the action of ambient sunlight.

The same phenomenon occurred in the case of sample Nt 2.6, for which a much lower result of the breaking strength compared to Nt 0 was obtained. Good results were also obtained for the Nt 2.3 and $\mathrm{Nt} 2.2$ samples, according to the burial depth. The sample $\mathrm{Nt} 2.2$ contrary to the unaltered morphology of the fibres had poor tensile strength compared to $\mathrm{Nt} 0$, and even the thickness decreased. A special case is the Nt 2.1 sample which did not show a decrease in tensile strength and elongation at break compared to the Nt 0 sample, although it was buried deepest in the soil, and damage to the fibres identified under the microscope would have indicated significant biodegradation.

Good results were also obtained for the samples of the $\mathrm{Nt} 3$ set, all the values of the tensile strength were below the reference sample tensile strength or even close, like in the case of $\mathrm{Nt} 3.1$ sample, which also had the same thickness as $\mathrm{Nt} 0$ sample, and no significant morphological changes of the fibres were observed under SEM analysis. Like the Nt 2.1 sample, this one does not necessarily conform to the influence of burial depth.

It should be noted that after calculating the coefficients of variation (CV) for the realized measurements, in some cases (Nt 2.3, Nt 2.6 and Nt 3.2) this indicator recorded high values indicating a large dispersion of the recorded data, which is normal in the case of nonwovens with a high degree of thinness $(<1 \mathrm{~mm})$ and with possible non-uniformities in the nonwoven mass, although they showed the lowest tensile strength. The best value was obtained for the sample Nt 3.4 with a tensile strength of $380.75 \mathrm{~N}$ and an adequate $\mathrm{CV}$.

According to the tensile test, for the Nt 3 set of samples, it seems that the burial period of 10 months had a much better influence than the burial depth. It took a minimum of 10 months for all the samples to show a decrease in tensile strength. 


\section{CONCLUSIONS}

PLA fibres are currently a sustainable solution for the development of agro-textiles used as filtration and/or support media for the harmonious growth of crops, both at underground levels or even laid on the soil surface. The developed analyse underline the following:

- The biodegraded nonwoven samples did not change colour and do not lose their shapes due to degradation.

- PLA nonwoven changed only at the surface level where the fibres came out of the structure, creating a flaky type effect.

- All the analysed samples went through some internal structure degradation, which was best manifested by the loss of mechanical properties.

- The results showed that for this type of textile material, tensile strength decline does not necessarily correlate with mass measurements after degradation because due to the structure of nonwoven, it retains a large amount of residual soil among the spaces between the fibres which cannot be cleaned.

- The best tensile strength results were obtained for $\mathrm{Nt} 3$ set of samples, which indicates that the 10-month burial period had a significant influence compared to 8 and 9 months of burial.

- Overall, the material under study withstood the biodegradation process quite well during the 10 months, only after this period registering a substantial decrease in mechanical properties.

- Thus, we can mention that the mixture soil-compost as a biodegrading medium, without well controlled process conditions and without the addition of inoculant material, is a medium that does not favour rapid degradation of the material.

The applicability of such material from polylactic acid fibres in agricultural practices, as mulching material, could be an environmental-friendly and cost-effective solution for crops growing. Moreover, the reaction products, $\mathrm{CO}_{2}$ and $\mathrm{H}_{2} \mathrm{O}$, from the biodegradation process will help the crops to develop harmoniously. In addition, according to this study, it can be used for a relatively long period, for at least two cultivation cycles, if we consider that one cycle begins in March and ends in November. At the end of its use, it can be disposed of at ground level or buried; it will finally degrade, leaving no residues in the environment and thus becoming biomass for future crops.

Further research work can be done on this matter for the enrichment of knowledge. Other types of biobased polymer fibres can also be considered for the production of textile structures that can be integrated into agricultural activities for the intelligent and sustainable valorisation of the agricultural lands, of the labour force and the improvement of the crops productivity and quality. Moreover, biodegradability in open environment, under real testing conditions will be a major step in the appreciation of the full potential of the use of these polylactic acid nonwovens as agro-textiles. The correlation of the data obtained in the laboratory tests with those obtained in the open environment tests, will allow the establishment of a realistic evaluation on the impact of this material on the environment. It is necessary to obtain more data that will allow seeing exactly how the material will resist in terms of durability and if it ensures the optimal conditions for crops growth.

\section{ACKNOWLEDGMENTS}

This work is funded by the UEFISCDI Romania, within PN III, 1st Program/Subprogram 1.2 - Institutional Performance - Complex projects completed in R\&D consortia, project no. 11PCCDI/ 2018-2021.

\section{REFERENCES}

[1] European Court Of Auditors, EU action to tackle the issue of plastic waste, Review No. 4, 2020, Available at: https://www.eca.europa.eu/Lists/ECADocuments/RW20_04/RW_Plastic_waste_EN.pdf [Accessed on May 2020]

[2] Scarascia, G., Sica, C., Russo, G., Plastic materials in European agriculture: Actual use and perspectives, In: Journal of Agricultural Engineering, 2011, 42, 3, https://doi.org/10.4081/jae.2011.3.15

[3] Envinromental Investigation Agency, Fields of Plastics: The growing problem of agriplastics, 2018, Available at: https://eia-international.org/about-us/reports/page/2/?report-year\&report-category=ocean\&report-subcategory [Accessed on May 2020]

[4] Brinsko, K.M., Sparenga, S.B., King, M.B., Examining the Effects of Environmental Degradation on the Optical Properties of Manufactured Fibers of Natural Origin-Report, 2016, Available at: https://www.ojp.gov/pdffiles1/nij/ grants/249911.pdf [Accessed on May 2020]

[5] Gutierrez, R.J., PLA Plastic/Material: All You Need to Know, 2020, Available at: https://all3dp.com/1/pla-plasticmaterial-polylactic-acid [Accessed on May 2020]

[6] Velrajan, M., Evaluation of Biodegradation of Plastics, In: International Journal of Innovative Research and Development, 2014, 3, 7

[7] Yabannavar, A.V., Bartha, R., Methods for Assessment of Biodegradability of Plastic Films in Soil, In: Applied and Environmental Microbiology, 1994, 60, 10, 3608-3614, https://doi.org/10.1128/AEM.60.10.3608-3614.1994

[8] Rudnik, E., Briassoulis, D., Degradation behaviour of poly(lactic acid) films and fibres in soil under Mediterranean field conditions and laboratory simulations testing, In: Industrial Crops and Products, 2011, 33, 3, 648-658, https://doi.org/10.1016/j.indcrop.2010.12.031

[9] Râpă, M., Popa, M. E., Cinelli, P., Lazzeri, A., Biodegradable alternative to plastics for agriculture application, In: Romanian Biotechnological Letters, 2011, 16, 6, 59-64 
[10] Sular, V., Devrim, G., Biodegradation Behaviour of Different Textile Fibres: Visual, Morphological, Structural Properties and Soil Analyses, In: Fibres and Textiles in Eastern Europe, 2019 27, 1, 100-111, https://doi.org/10.5604/01.3001.0012.7751_

[11] Xu, L., Crawford, K., Gorman, C.B., Effects of Temperature and pH on the Degradation of Poly(lactic acid) Brushes, In: Macromolecules, 2011, 44, 12, 4777-4782, https://doi.org/10.1021/ma2000948

[12] Paul, M., Cadar, O., Cadar, S., Chintoanu, M., Cioica, N., Fenesan, M., Balea, A., Pascalau, V., Biopolimeri Naturali - Sursa de Materie Prima în Realizarea Ambalajelor Biodegradabile în Vederea Protejarii Mediului, In: ProEnviroment, 2011, 4, 7, 139-146

[13] Patrycja, M.K., Karolina, G.J., Michał, K., Physicochemical Assessment of the Biodegradability of Agricultural Nonwovens Made of PLA, In: Fibres \& Textiles in Eastern Europe, 2021, 1, 145, 26-34, https://doi.org/ 10.5604/01.3001.0014.2398

[14] Wilfred, O., Tai, H., Marriott, R., Liu, Q., Tverezovskiy, V., Curling, S., Tai, H., Fan, Z., Wang, W., Biodegradation of Polylactic Acid and Starch Composites in Compost and Soil, In: International Journal of Nano Research, 2018, 1, 2, 01-11

[15] Sintim, H.Y., Bary, A.I., Hayes, D.G., Wadsworth, L.C., Anunciado, M.B., English, M.E., Bandopadhyay, S., Schaeffer, S.M., DeBruyn, J.M., Miles, C.A., Reganold, J.P., Flury, M., In situ degradation of biodegradable plastic mulch films in compost and agricultural soils, In: Science of The Total Environment, 2020, 727, 1386682020, https://doi.org/10.1016/j.scitotenv.2020.138668

[16] Karamanlioglu, M., Environmental degradation of the compostable plastic packaging material poly(lactic) acid and its impact on fungal communities in compost, 2013, Available at: https://www.escholar.manchester.ac.uk/api/ datastream?publicationPid=uk-ac-man-scw:201169\&datastreamld=FULL-TEXT.PDF [Accessed on May 2020]

[17] Janczak, K., Dąbrowska, G.B., Raszkowska-Kaczor, A., Kaczor, D., Hrynkiewicz, K., Richert, A., Biodegradation of the plastics PLA and PET in cultivated soil with the participation of microorganisms and plants, In: International Biodeterioration \& Biodegradation, 2020, 155, 1050872020, https://doi.org/10.1016/j.ibiod.2020.105087

[18] Hoshino, A., Isono, Y., Degradation of aliphatic polyester films by commercially available lipases with special reference to rapid and complete degradation of poly(L-lactide) film by lipase PL derived from Alcaligenes $s p$, In: Biodegradation, 2002,13, 2141-7, https://doi.org/10.1023/A:1020450326301

[19] Satti, S.M., Shah, A.A., Marsh, T.L.., Auras, R., Biodegradation of Poly(lactic acid) in Soil Microcosms at Ambient Temperature: Evaluation of Natural Attenuation, Bio-augmentation and Bio-stimulation, In: Journal of Polymers and the Environment, 2018, 26, 3848-3857, https://doi.org/10.1007/s10924-018-1264-x

[20] Grima, S., Bellon-Maurel, V., Silvestre, F., Feuilloley, P., A New Test Method for Determining Biodegradation of Plastic Material Under Controlled Aerobic Conditions in a Soil-Simulation Solid Environment, In: Journal of Polymers and the Environment, 2001, 9, 39-48, https://doi.org/10.1023/A:1016044504688

[21] California Department of Resources Recycling and Recovery, Report Topic - PLA and PHA Biodegradation in the Marine Environment, 2012, Available at: https://www2.calrecycle.ca.gov/Publications/Download/1006?opt=dln [Accessed on May 2020]

[22] Castro-Aguirre, E., Auras, R., Selke, S., Rubino, M., Marsh, T., Enhancing the biodegradation rate of poly(lactic acid) films and PLA bio-nanocomposites in simulated composting through bioaugmentation, In: Polymer Degradation and Stability, 2018,154, 46-54, https://doi.org/10.1016/j.polymdegradstab.2018.05.017

[23] Leejarkpai, T., Suwanmanee, U., Rudeekit, Y., Mungcharoen, T., Biodegradable kinetics of plastics under controlled composting conditions, In: Waste Management, 2011, 31, 6, 1153-1161, https://doi.org/10.1016/ j.wasman.2010.12.011

[24] Subtirica, A.I., Banciu, C.A., Chivu, A.A.-M., Dinca, L.C., Nanofibres made from biocompatible and biodegradable polymers, with potential application as medical textiles, In: Industria Textila, 2018, 69, 1, 55-58, http://doi.org/10.35530/IT.069.01.1502

\section{Authors: \\ CRISTINA ELENA STROE ${ }^{1}$, TEODOR SÂRBU ${ }^{1}$, VASILICA MANEA ${ }^{2}$, FLOAREA BURNICHI ${ }^{2}$, DUMITRU MITEL TOMA², CATĂLINA TUDORA ${ }^{3}$ \\ ${ }^{1}$ National Research and Development Institute for Textiles and Leather, 16 Lucretiu Patrascanu Street, 030508, Bucharest, Romania}

${ }^{2}$ Vegetable Research and Development Station - SCDL Buzau, 23 Mesteacanului Street, 120024, Buzau, Romania

${ }^{3}$ National Research and Development Institute for Machines and Installations for Agriculture and Food Industry, 6 Ion Ionescu de la Brad Avenue, 013813, Bucharest, Romania

\section{Corresponding author:}

CRISTINA ELENA STROE

e-mail: cristina.stroe@incdtp.ro 